\title{
FOREIGN EXPERIENCE IN FORMING SOCIAL COMPETENCY OF FUTURE SPECIALISTS IN SERVICE SECTOR
}

\begin{abstract}
Foreign experience in forming social competency of future specialists in service sector being the system of social, psychological and pedagogical knowledge, skills, life and professional experience, values, motives of life activities and personal qualities that makes it possible to effectively execute social functions in the society has been revealed in the article. The specificity and influence of the educational process in the educational establishment on the forming of social competency of a student's personality have been analyzed. The social competency requires from an individual such qualities as integrity, ability to protect his/her own opinion, to resist unwanted influence as well as tolerance and the ability to adapt and, moreover, to operate effectively in constantly changing social conditions. The socially competent person should not only understand the nature and the specific character of a situation or a problem, but also be able to solve it practically, be motivated to do it, be able to analyze both his/her own performance and its consequences. The study of theory and practice of training specialists in service sector has showed that nowadays there are only few researches dedicated to theoretical study and approbation of the content and methodology of forming social competency of future specialists in service sector.

Key words: social competency, educational process, social environment, education, knowledge, abilities, skills, active learning methods, Belarus, Kazakhstan, Russia.
\end{abstract}

\section{INTRODUCTION}

The topicality of the problem of forming social competency of future specialists in service sector is determined by the fact that the system of higher professional education should provide future specialists with effective tools for life and professional adaptation under fragile and unstable social conditions, form value orientations and practical skills for effective interaction in society. Indeed, the strategic task of education and the educational process, in particular, is the development of an individual, his/her intellectual abilities, and the ability to realize oneself in research activities, which promotes proper training of future specialists.

\section{THE AIM OF THE STUDY}

The aim of the study is to reveal the peculiarities of forming social competency of future specialists in service sector in foreign countries (Belarus, the Republic of Kazakhstan, Russia).

\section{THEORETICAL FRAMEWORK AND RESEARCH METHODS}

The ideas of such foreign researchers as D. Rushen, M. Scott, D. Vos contribute to understanding the essence of competency approach in education. Recenly the problem of competency approach to educational content and its certain aspects has drawn the attention of famous domestic scholars. In fact, the significant contribution to the definition of methodological principles of the problem is in the views and ideas of $\mathrm{K}$. Abulkhanova- 
Slavska, A. Asmolova, V. Davydova, V. Shadrykov, F. Vasyliuk, L. Vyhotskyi, I. Zarubinska and others. The definition of the nature of social competency is described in the works of A. Arhail, P. Berelson, A. Holdshtein, S. Honcharov, M. Doktorovych, V. Kunitsyna, D. Raven,O. Skirko, I. Zarubinska, Yu. Zhukov and others. Some aspects of forming students' social competency in higher educational establishments are analyzed in the scientific researches by O. Mykhailov, S. Racheva, R. Skirko, V. Turchaninova, O. Usyk, I. Zarubinska, and others.

In our research we used such research methods as analysis of scientific sources, comparison, synthesis and generalization to study official and legal documents, scientific works by domestic and foreign scientists, scientific and methodological information provided on the websites of universities.

\section{RESULTS}

Nowadays the graded structure of staff training enables to quickly rebuild the educational process in accordance with the changing needs of production due to the changes in direction, level, content, forms and means of education. The significant role in this process is played by colleges which enable to realize the needs of individuals in the cultural and moral development and create conditions for their professional growth and self-improvement.

Analysis of foreign researches has enabled to define the basic principles of multilevel training of specialists in service sector in the post-Soviet countries, among which we can highlight the following: activity-orientation of professional education; content mobility of professional education; interactivity of educational programs; advanced training (Козловская, 2003)

Most scientists believe that it is necessary to apply innovative technologies to improve the quality of educational process in higher educational establishments. Thus, according to L. Nasyrova it is necessary to ensure thorough training of teaching staff, to implement variable practical training of students, to utilize a variety of organizational forms of lessons, namely, independent work, research etc. (individual forms); simulation games, role-playing, business and practical lessons (collective forms). These changes will have a positive impact on development of students' thinking. The using of active methods of independent creative activity by students, modeling of professional activities aimed at developing of students' specific cognitive needs will ensure professional development in the future profession (Насырова, 2010).

Known not only in Belarus but also abroad is the Minsk State Trade College which since 2015 was reorganized into a branch of the Belarus State Economic University called "The Minsk State Trade College". After finishing the college, graduates have the right to enter the Belarus State Economic University and study full-time and part-time by a shortened program. The agreements are also signed with 19 universities of Belarus and the Russian Federation.

The content of forming students' social competency in the Minsk State Trade College consists in creating vitally active personality through designing such content of teaching and education of students which would most contribute to the forming of their socially significant abilities (to analyze their own and others' actions; to experiment and make decisions; to understand the value of knowledge in production processes and the need to deepen it and to ensure social cohesion and professional development; willingness to solve professional problems related to the social nature of human) and can be implemented through the prism of educational work on forming social competency and the system of curricular and extracurricular activities in college as well as regulation and self-creative activity of students. 
At this university the academic work is closely linked with education. In particular, students together with masters of vocational training conduct master classes where one can learn how to make funny figures of animals and birds of dairy mastics and cut flowers and vases of vegetables.

The students have been actively participating in the charity event called "Good Heart" for several years already. They organized the collection of stationery, objects of artistic creativity, board games and toys, children's books for the children of the Radoshkovitsky Orphanage and for those who are in social and educational center of the Soviet District in Minsk. More than 20 educational groups led by tutors took part in the event.

The Shymkent Cooperative College or presently the Shymkent Economic College was established on April 8,1958. The college has a license to conduct educational activities issued by the Ministry of Education of the Republic of Kazakhstan since April, 2000. Over the years the college has trained more than 18,000 specialists. Now the educational work in the college is carried out by the qualified teachers united in cyclic commissions. The work of teaching staff is directed to the education of socially active, innovatively thinking specialists who are in demand in the labour market (Шимкентський экономический колледж, 2015).

To study the theoretical grounds of information and communication technologies, to develop the common approach to research problems, to share the experience of college teachers for two academic years, the methodical service involved teachers, organized and conducted activities of various forms such as seminars, conferences, teachers' meetings, workshops, professional weeks, "School of Young Teachers" etc. Competitive, socially active specialists can be prepared only by highly professional, erudite and mobile teachers (Минский торговый колледж, 2015).

In the state budget educational establishment of secondary education "Krasnodar Trade and Economic College" of Krasnodar Region the area of social partnership in the field of quality education is expanded, the network cooperation with educational institutions and enterprises is being developed, the optimization of methods, technologies, training, expansion of information and communication technologies facilitating to the forming of general and professional competencies of future specialists in service sector is being carried out.

This college gradually accumulates the practical experience of using information technology in the educational process, namely, the new models of teaching have been tested and the new pedagogical practice has appeared. For example, the use of electronic textbooks and their fragments and other audiovisual means in educational process promotes the cognitive interest of students, increases motivation to study disciplines, interdisciplinary courses, which, in its turn, affects the forming of social competency. Modern technical training means are actively used, including interactive whiteboard, document camera, interactive inquiry system "SMART", projector (Краснодарский торгово-экономический колледж, 2015).

According to D. Egorov, the concept of social competency may refer to both an individual or the whole social group and it provides for not only a system of knowledge, skills and experience, but also a forming of life and professional values, independence, a certain level of education and ability to effectively solve new, unconventional tasks (Егоров, 2003).

We believe that "the social competency of future specialists in service sector" is a comprehensive characteristic of a future specialist which contains a system of social, psychological and pedagogical knowledge, skills, professional experience, values and 
motives of life and personal qualities that enable to effectively fulfill social functions within the competency of the specialist.

The forming process of social competency has the humanistic, civic, axiological, creative, reflective orientation and facilitates to maximum self-disclosure, self-determination, selfdevelopment, self-expression and socialization, demonstrations of independence, initiative, leadership traits of an individual, learning of positive stereotypes and algorithms of social behavior, socially significant activities, solutions to social problems, improvement of social and individual status, development of self-confidence of future specialists (Мищенко, 2004).

Studying the foreign experience of forming social competency of future specialists we found many similarities in its interpretation. This is because the nature and scale of the tasks solved by a society in post-Soviet countries (Belarus, the Republic of Kazakhstan, Russia) during the last decade show certain specificity in the forming of social competency. The views of philosophers and teachers on the interpretation of this phenomenon are similar as the scientists understand it as possessing methods of cooperation, collaboration, communication as well as leadership and social responsibility for the results of own activities.

On the basis of psychological and educational literature we have defined the purpose of forming the social competency of future specialists in service sector as providing the young students with the system of social knowledge, skills, experience, values, skills and abilities and developing skills to carry out effective social interaction, to predict the effects of social behavior, self-administration, achieving social success. So, the social competency of a specialist determines the readiness to independently solve tasks related to social life, to evaluate the results of own activities as required by society.

The social competency is the result of professional training of future specialists in college and is evident as being ready to creatively solve professional tasks. Therefore, the educational process in an educational establishment is an important factor in forming the social competency of a student's personality. The professional training of future specialists is focused on acquiring knowledge and skills by students, i.e. on the forming of the cognitive component of social competency.

The forming of future specialists' social competency is the organizational system of cognitive, search creative, independent work of students. In our opinion, the approach of $\mathrm{O}$. Bodalev on the forming of any phenomenon is rather constructive, including the social competency as a unity of knowledge, experiences (motives) and behavior, so this process should reflect the forming of cognitive, emotional, motivational and behavioral components in the structure of the phenomenon under study. Thus, the forming of an individual happens owing to the system of knowledge acquired by a person in the process of perceiving reality through emotional experience and different actions (Бодалев, 1996).

The success in the forming of future specialists' social competency depends on properly selected methodological approaches to the development of methodology and its implementation in teaching practice.

According to the foreign experience (Belarus, the Republic of Kazakhstan, Russia) in the forming of college students' social competency this phenomenon is affected by the social and personal factors. Among the social factors we identified the socio-economic situation, the educational environment of the college teaching methods, norms, rules of behavior, traditions, organization of students' free time, their involvement in volunteer work and so on. Determination of the specific forming of students' social competency in the college educational environment is impossible without the final generalization in understanding of this phenomenon and combining its components in meaningful unity. This 
is important for planning purposes for forming social competency and determination of the main directions of educational activities through which these objectives will be implemented.

The environment implies social and living conditions in which people live; natural conditions an organism lives in; matters, bodies filling the space and possessing certain properties (Мищенко, 2004). We consider the educational environment of the college to be a part of general educational space in which the sociality of an individual is formed due to the purposeful, scientifically grounded and systematic educational activities for the effective social forming of a person, turning him/her into an active subject of social development and society. In the college educational environment the conditions for the harmonization of social and individual in the process of personal development, social development, the individual's entering society, and the most important, the social conditions of learning and education improve. The educational institution is an institution which, firstly, is already educational environment, secondly, requires the creation of social and educational environment through diversification of relations with the social environment. This is due to the necessity of intense social development of students, implementation of educational, cognitive and creative activity.

Changing the content of education, competency approach imposes the same effect on selection of educational methods. Therefore, teachers prefer active, interactive methods of teaching and education. The organization of interactive training provides the simulation of life situations, the use of role-play games and the joint solution of problems by analyzing the relevant circumstances and situations. It effectively promotes forming of skills and habits, development of values, creation of atmosphere of cooperation and interaction (Чередов, 1988). The interactive communication exclude both the dominance of one party over the other in the learning process and one thought over another one. During interactive learning students learn to be democratic; to communicate with others; to avoid conflict situations; to think critically; to make thoughtful decisions. So, their social competency is formed.

With interactive learning the educational process is organized so that almost all the students involved in training activities are able to act according to knowledge available. Joint activities in the process of learning means that everyone is making a personal contribution, the exchange of knowledge, ideas and ways of working is carried out. And it all happens upon condition of mutual support and in the atmosphere of goodwill that enables not only to acquire new knowledge, but also to form humane relationships, sense of responsibility, culture of communication, i.e. social competency.

The personal factors include the corresponding general culture, values, the psychological state and the level of social thinking, the personal mindset of students, their social activity and self-education.

As it was noted by I. Zarubinska the important factor for establishment and development of socially competent behavior of an individual is self-education, i.e. conscious human activity aimed at forming and improving his/her own skills in accordance with social or individual values, preferences, interests and goals which are formed under the influence of living conditions and public education. The importance of self-education in order to develop social competency of students in colleges is determined by the continuity of the process and the need for flexible adaptation to social conditions and the general situation in the development of society. This makes the forming of the students' needs and abilities of developing influence on their own personality to be the priority goal. The specificity of self-education is that it relies on the individual characteristics of a person, 
his/her inclinations and needs. Self-education defines the special value of a person in the context of realization of objectives of social competency of students as the competent social behavior involves the activation of compensatory mechanisms. One of the elements of selfeducation is the active independent work of students aimed at acquiring of appropriate knowledge, skills and abilities of socially competent behavior. The skills of independent work of students are largely determined by the efficiency of development and improvement of social competency after graduation from an educational establishment (Зарубінська, 2011).

According to the experience in training specialists in service sector in Belarus, the Republic of Kazakhstan and Russia the forming of social activity, social responsibility, tolerance, altruism under the condition of goal-directed educational activities in the environment of a college, in our opinion, will facilitate the forming of social individuality and social maturity. It is sociality as the ability to interact with the social world that is most effectively formed in the pedagogical environment of the college, since there is a possibility to perform all the functions of educational activities. Such forming is different as there is the largest number of educational influences being effectively combined which enables the implementation of educational problems. It should be noted that the effective training and educational activities are implemented in a pedagogical environment which enables to diagnose already established signs of social competency and is the factor of further increasing of its level. The educational activities in the pedagogical environment of the college are carried out at the internal and external levels. It is fundamental, because, thus, the social contacts are expanded in the education of students. But the social contacts are selected and directed according to a specific educational goal, namely, forming of social competency.

The organization of students' development in college is determined by the factors of external level, because an educational establishment is an open organization where there is a possibility to contact governmental, social and public institutions and other educational establishments, families of students and others. At the same time the teaching activities at the internal level are carried out by taking into account the functions of the educational establishment as well as according to the educational spheres of the college (traditions, selfgovernment, leisure, social and political activities, training, volunteering etc.). These are the areas that are chosen as primary, as each of them has its influence on the forming of social competency (Колобова, 2003).

\section{CONCLUSIONS}

Hence, it is important to understand that the integrity and interdependence, systemacity of the educational environment is the factor of forming the social competency of the student's personality. Therefore, the integrity and interdependence, systemic educational environment as the factor for the forming of social competency of the student's individuality should be emphasized. Studying the foreign experience in forming the social competency of future specialists in service sector it has been revealed that the components of the educational environment being conducive to the forming of students' social competency are training, education, students' self-government, leisure, social activities, traditions of college, volunteering, i.e. those components that integrally ensure the development of conflict-free manner of behavior, independent thinking, fast adaptation to a changing environment, the ability of self-development and form students' social competency.

The issues of interactive technologies implementation into the learning process which are effectively used for forming social competency of future specialists in service sector in neighboring countries require further consideration. 


\section{REFERENCES}

1. Бодалев, А. (1996). Психология общения: избранные психологические труды [Psychology of Communication : Selected Psychological Works]. M., 356 p. (in Russian).

2. Безпалько, O. (2003). Соиіальна педагогіка в схемах і таблииях: навчальний посібник [Social Pedagogy in Figures and Tables : Tutorial]. Київ : Центр навчальної літератури, 114 p. (in Ukrainian).

3. Егоров, Д. (2003). Формирование сочиальной компетентности студента среднего профессионального ученого заведения в процессе соиіального образования [Social Competency Forming of Secondary Vocational Schools Students during Social Education]. Thesis for PhD. Казань, 286 p. (in Russian).

4. Зарубінська, I. (2011). Теоретико-методичні основи формування соиіальної компетентності студентів вищих навчальних закладів економічного профілю [Theoretical and Methodological Basis of Social Competency Forming of Students in Higher Education Institutions with Major in Economics]. Thesis for Doctoral Degree. Київ, 346 p. (in Ukrainian).

5. Колобова, О. (2003). Формирование соииальной компетентности выпускников классического университета: на примере изучения иностранного язика [Social Competency Forming of Classical University Graduates: on the Example of Foreign Language Study]. Thesis for PhD. Рязань, 304 p. (in Russian).

6. Козловская, Л. (2003). Многоуровневая подготовка специалистов сферы обслуживания в системе профессионального образования - «колледж-ВУЗ»: [Multilevel Training of Specialists in Service Sector in the System of Professional Education "College-Higher Education Institution"]. Abstract of Thesis for PhD. Сходня, 28 p. (in Russian).

7. Краснодарский торгово-экономический колледж [Krasnodar Trade Economic College]. (2015). Retrieved 23.09.2015 from : http://www.ktek23.info/institution/.

8. Минский торгово-экономический колледж [Minsk Trade Economic College]. (2015). Retrieved 12.06.2015 from : http://www.mgtk.by/index.php?option=com_content\& task= $\mathrm{view} \& \mathrm{id}=12 \&$ Itemid $=1$.

9. Міщенко, I. (2004). Дидактичні умови формування психолого-педагогічної компетентності майбутніх викладачів економіки в процесі професійної підготовки [Didactic Conditions of Psychological and Pedagogical Competency Forming of Future Teachers of Economics during Professional Training]. Thesis for PhD. Київ, 274 p. (in Ukrainian).

10. Насырова, Л. (2010). Обучение студентов туристского колледжа дополнительным профессиям в сфере гостеприимства [Teaching Additional Proffesions in the Field of Hospitality to Students of a Tourist College]. Abstract of Thesis for PhD. Москва, 32 p. (in Russian).

11. Чередов, И. (1988).Формы учебной работы в средней школе / Книга для учителя [Forms of Educational Work in Secondary Schools / Book for Teachers]. Москва : Просвещение, 208 p. (in Russian).

12. Шимкентський экономический колледж [Shymkent Economic College]. (2015). Retrieved 23.09.2015 from : http://shek-kps.kz/rindex.html. 